\title{
Anemia in Children under 5 years, The Prevalence and Contributing Factors in Al-Batool Teaching Hospital/Diyala Governorate
}

Mehdi SH Al-Zuheiry (FICMS) ${ }^{1}$,Nadhim Ghazal Noaman $(\mathrm{PhD})^{2}$ and Ali Ammer Abd $(\mathrm{Msc})^{3}$

\begin{abstract}
Background: Anemia is a worldwide public health problem, with significant outcomes for health social and economic growth of each country. Anemia is a hemoglobin concentration two standard deviation lower than the mean hemoglobin concentration for a normal population range of the same age and gender.

Objective: To assess the prevalence of anemia in children and its contributing factors under 5 years old in Diyala/Iraq.

Patients and Methods: A prospective cross sectional study was conducted at Al-Batool maternity and children teaching hospital from the first of August 2017 to first of January 2018. Five hundreds of children from the six months to five years old were included in the current study.

Results: The percentage of anemia in the studied sample was 142 (28.4\%), from which 104 (73.5\%) was iron deficiency anemia, $2(1.1 \%)$ was thalassemia major and intermedia and 6 $(4.4 \%)$ was B-thalassemia trait and $30(21 \%)$ other type of anemia. There were a highly significant association between anemia and artificial feeding, prolonged breast-feeding, tea consumption, worm infestations, absence of prenatal care, low birth weight, low parental education and low wealth index. They were a significant association between anemia and male gender, rural residency and positive family history of anemia.

Conclusion: Anemia still represents a major health problem in children under 5 years in Diyala province with prevalence of 142 (28.4\%), most of them $104(73.5 \%)$ was iron deficiency anemia.
\end{abstract}

Keywords: Children, Anemia, Prevalence, Contributing factors, Diyala province.

Corresponding Author: aliamertemem174@gmail.com

Received: $29^{\text {th }}$ September 2019

Accepted: $25^{\text {th }}$ December 2019

DOI:https://doi.org/10.26505/DJM.18024970929

\footnotetext{
${ }^{1,2}$ College of Medicine - University of Diyala - Diyala -Iraq

${ }^{3}$ Diyala health directorate -Alkhalis Hospital- Diyala -Iraq
} 


\section{Introduction}

Anemia is a worldwide public health problem, with significant outcomes for health social and economic growth of each country [6]. It caused by single or multiple causes that act separately influencing child's health [13], their immunity, physical , cognitive and development and increasing the risk of infant mortality and infections [22] .

Definitions: Anemia: is a hemoglobin $(\mathrm{Hb})$ concentration two standard deviations below the mean $\mathrm{Hb}$ concentration for a normal population range of the same age and genre, as defined by the United Nations Children's fund, United Nations University and World Health Organization[22].

Epidemiology: Anemia in pediatrics bearing a major public health problem leading to an increased risk of mortality, in addition to the negative outcomes of irondeficiency anemia on physical and an intellectual development. In 2003, the United Nations General Assembly set an aim to decrease the prevalence of anemia by one third by 2010 (Kassebaum N et al, 2010), Even though this, the incidence of anemia in children aged under 5 between 1990-2010 increased [23].

\section{Patients and Methods}

Five hundred children with age from (6 month) to (5 years) old were included in the study. The data collected by special questioning sheet from patients in the emergency room and wards in Al-Batool Teaching Hospital. Information about sociodemographic characteristic, information of patients were taken from their mothers or relatives, including name, age, gender, residency, weight, height, and number of children in family. Other information's include type of feeding, time and type of weaning, history of acute or chronic illness and its duration, the family history of anemia, history of regular health care, duration of pregnancy, history of tea consumption. History of worm infestation, and socioeconomic state of family. Wealth index were measured for each patients, information on the wealth index is based on data collected in the Household Questionnaire.

Ethical consideration: The purpose and procedures explain to all parents participants and were give the right to participate or not, with reassurance that interpret gained will be kept confidentially.

\section{Statistical analysis}

All patients' data entered using statistical PC software; (SPSS) Statistical Package for Social Sciences version 21 were used, statistics presented as (mean \pm standard deviation) and percentages. Level of significance ( $\mathrm{p}$ value) set at $(\leq 0.05)$ and the result presented as tables and/or graphs, in all statistical analysis.

\section{Results}

The percentage of anemia in the studied sample was 142 (28.4\%), from which 104 $(73.5 \%)$ was iron deficiency anemia, 2 $(1.1 \%)$ was B-thalassemia major and intermedia and $6(4.4 \%)$ was B-thalassemia trait and $30(21 \%)$ other type of anemia. 
Anemia in Children under 5 years, The Prevalence and Contributing Factors in Al-Batool Teaching

Table (1): The percentage of different types of anemia in the study

\begin{tabular}{|l||c|c||}
\hline Variable & No. (142) & \% \\
\hline \hline Type of anemia & 104 & 73.5 \\
\hline \hline Iron deficiency anemia & 6 & 4.4 \\
\hline \hline Beta Thalassaemia Trait & 2 & 1.1 \\
\hline \hline Beta Thalassaemia major and intermedia & 30 & 21 \\
\hline \hline $\begin{array}{l}\text { Other types of anemia : anemia of chronic disease like } \\
\text { renal and liver diseases, Bone marrow failure } \\
\text { hemolytic anemia, anemia after blood loss, vitamin } \\
\text { B12 and folate deficiency and a plastic anemia. }\end{array}$ & 142 & 100.0 \\
\hline \hline Total & & \\
\hline
\end{tabular}

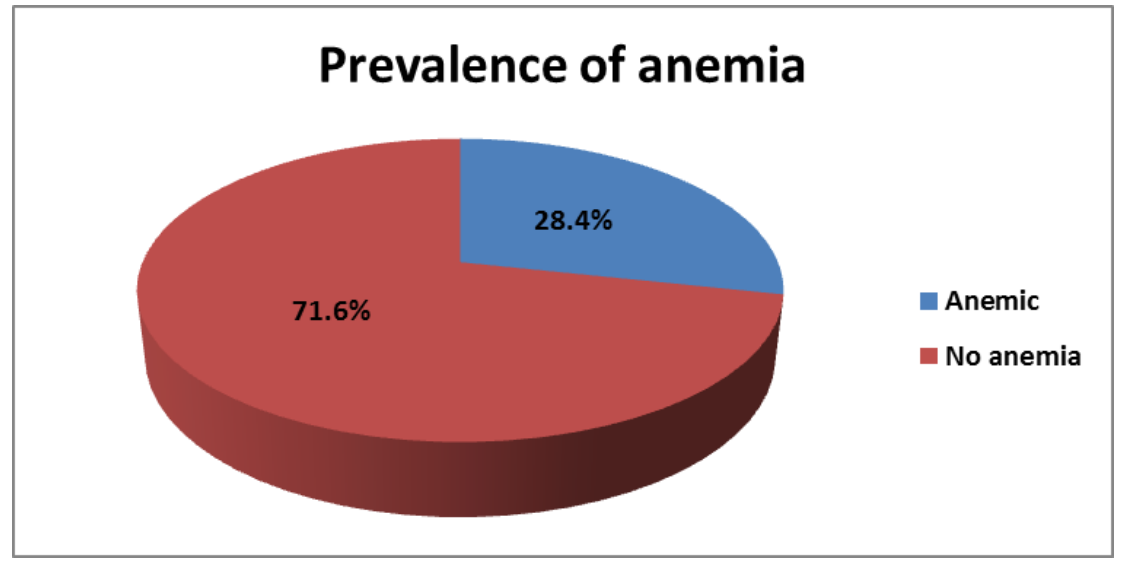

Figure (1): Prevalence of anemia

There was a highly significant difference between children without maternal prenatal care and anemia $(\mathrm{p}<0.001)$. Moreover a highly significant differences were observed between anemic and not anemic children regarding maternal iron intake and prenatal anemia $\quad(p<0.001) . \quad$ Highly significant association was found between anemic and not anemic children regarding place of delivery. A highly significant association was observed between low birth - weight children and anemia $(\mathrm{p}<0.001)$. Children with history of prematurity were significantly associated with anemia $(\mathrm{p}=0.01)$.No significant association were found between type of delivery and anemia $(p=0.2)$.As shown in Table (2). 
Anemia in Children under 5 years, The Prevalence and Contributing Factors in Al-Batool Teaching

Table (2): Anemia according to perinatal characteristics

\begin{tabular}{|c|c|c|c|c|c|}
\hline \multirow[t]{2}{*}{ Variable } & \multicolumn{2}{|c|}{ Anemia } & \multicolumn{2}{|c|}{ No anemia } & \multirow[t]{2}{*}{$\mathrm{P}$} \\
\hline & No. & $\%$ & No. & $\%$ & \\
\hline \multicolumn{5}{|l|}{ Prenatal care } & \multirow{3}{*}{$<0.001 * \mathrm{~S}$} \\
\hline Yes & 8 & 5.6 & 358 & 100.0 & \\
\hline No & 134 & 94.4 & 0 & 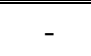 & \\
\hline \multicolumn{5}{|l|}{ Maternal Iron Intake } & \multirow{3}{*}{$<0.001 * \mathrm{~S}$} \\
\hline Yes & 7 & 4.9 & 348 & 97.2 & \\
\hline No & 135 & 95.1 & 10 & 2.8 & \\
\hline \multicolumn{5}{|l|}{ Maternal anemia } & \multirow{3}{*}{$<0.001 * * \mathrm{~S}$} \\
\hline Yes & 107 & 75.4 & 92 & 25.7 & \\
\hline No & 35 & 24.6 & 266 & 74.3 & \\
\hline \multicolumn{5}{|l|}{ Type of delivery } & \multirow{3}{*}{$0.2 * *$ NS } \\
\hline Normal vaginal delivery & 55 & 38.7 & 160 & 44.7 & \\
\hline Caesarian Section & 87 & 61.3 & 198 & 55.3 & \\
\hline \multicolumn{5}{|l|}{ Place of delivery } & \multirow{3}{*}{$<0.001 * * \mathrm{~S}$} \\
\hline Hospital & 42 & 29.6 & 254 & 70.9 & \\
\hline Midwives & 100 & 70.4 & 104 & 29.1 & \\
\hline \multicolumn{5}{|l|}{ Birth weight } & \multirow{4}{*}{$<0.001^{* *} \mathrm{~S}$} \\
\hline Low & 111 & 78.2 & 41 & 11.5 & \\
\hline Normal & 31 & 21.8 & 310 & 86.6 & \\
\hline Overweight & 0 & - & 7 & 2.0 & \\
\hline \multicolumn{5}{|l|}{ Prematurity } & \multirow{3}{*}{$0.01 * * \mathrm{~s}$} \\
\hline Yes & 127 & 89.4 & 16 & 4.5 & \\
\hline No & 15 & 10.6 & 342 & 95.5 & \\
\hline
\end{tabular}

*Fishers exact test, **Chi square test, $\mathrm{S}=$ Significant, NS=Not significant

No significant differences were observed between anemic and not anemic children regarding mothers' age. There was a highly significant association between the level of maternal and paternal education and anemia $(\mathrm{p}<0.001)$. There was a highly significant association between maternal unemployment and anemia $(\mathrm{p}<0.001)$. (We have a 9 dead mothers in this study Unfortunately). show in Table (3). 
Anemia in Children under 5 years, The Prevalence and Contributing Factors in Al-Batool Teaching

Hospital/Diyala Governorate

Table (3): Anemia according to parental socio-demographic characteristics

\begin{tabular}{|c|c|c|c|c|c|}
\hline \multirow[t]{2}{*}{ Variable } & \multicolumn{2}{|c|}{ Anemia } & \multicolumn{2}{|c|}{ No anemia } & \multirow{2}{*}{$\mathrm{P}$} \\
\hline & No. & $\%$ & No. & $\%$ & \\
\hline \multicolumn{5}{|l|}{ Mothers age } & \multirow{5}{*}{$0.3 * \mathrm{NS}$} \\
\hline$<20$ years & 6 & 4.2 & 7 & 2.0 & \\
\hline 20-29 years & 78 & 54.9 & 204 & 57.0 & \\
\hline 30-39 years & 256 & 39.4 & 136 & 38.0 & \\
\hline$\geq 40$ years & 2 & 1.4 & 11 & 3.1 & \\
\hline \multicolumn{5}{|c|}{ Mother educational level } & \multirow{5}{*}{$<0.001 * * \mathrm{~s}$} \\
\hline Primary level & 70 & 49.3 & 39 & 10.9 & \\
\hline Secondary level & 39 & 27.5 & 107 & 29.9 & \\
\hline College & 24 & 16.9 & 1774 & 48.6 & \\
\hline Higher education & 9 & 6.3 & 38 & 10.6 & \\
\hline \multicolumn{5}{|l|}{ Mother occupation } & \multirow{3}{*}{$<0.001 * \mathrm{~S}$} \\
\hline Housewife & 62 & 44.4 & 309 & 86.3 & \\
\hline Worker & 71 & 53.5 & 49 & 13.7 & \\
\hline \multicolumn{5}{|c|}{ Father educational level } & \multirow{5}{*}{$<0.001 * * \mathrm{~S}$} \\
\hline Primary level & 64 & 45.1 & 30 & 8.4 & \\
\hline Secondary level & 42 & 29.6 & 92 & 25.7 & \\
\hline College & 26 & 18.3 & 155 & 43.3 & \\
\hline Higher education & 10 & 7.0 & 81 & 22.6 & \\
\hline
\end{tabular}

There was a significant association between lower number of house rooms and anemia in children $(\mathrm{p}=0.02)$. A highly significant association was observed between tank and river water source and children with anemia $(\mathrm{p}=<0.001)$. Highly significant association was found between low wealth index and anemia in children $(\mathrm{p}=<0.001)$. No significant association were found between smoking and children with anemia. As shown in Table (4). 
Anemia in Children under 5 years, The Prevalence and Contributing Factors in Al-Batool Teaching

Hospital/Diyala Governorate

Table (4): Anemia according to environmental and economic characteristics

\begin{tabular}{|c|c|c|c|c|c|}
\hline \multirow[t]{2}{*}{ Variable } & \multicolumn{2}{|c|}{ Anemia } & \multicolumn{2}{|c|}{ No anemia } & \multirow[t]{2}{*}{$\mathrm{P}$} \\
\hline & No. & $\%$ & No. & $\%$ & \\
\hline \multicolumn{5}{|c|}{ House rooms number } & \multirow{3}{*}{$0.02 * \mathrm{~s}$} \\
\hline$\leq 2$ rooms & 124 & 87.3 & 280 & 78.2 & \\
\hline$>2$ rooms & 18 & 12.7 & 78 & 21.8 & \\
\hline \multicolumn{5}{|c|}{ Water source } & \multirow{4}{*}{$<0.001 * * \mathrm{~S}$} \\
\hline River & 56 & 39.4 & 354 & 98.9 & \\
\hline Tank & 74 & 52.1 & 0 & 0 & \\
\hline Pipe & 12 & 8.5 & 4 & 1.1 & \\
\hline \multicolumn{5}{|c|}{ Smoking in family } & \multirow{3}{*}{$0.3 * \mathrm{NS}$} \\
\hline Yes & 90 & 63.4 & 209 & 58.4 & \\
\hline No & 52 & 36.6 & 149 & 41.6 & \\
\hline \multicolumn{5}{|c|}{ Wealth index } & \multirow{4}{*}{$<0.001 * \mathrm{~S}$} \\
\hline Low & 94 & 66.2 & 104 & 29.1 & \\
\hline Medium & 30 & 21.1 & 207 & 57.8 & \\
\hline High & 18 & 12.7 & 47 & 13.1 & \\
\hline
\end{tabular}

\section{Discussion}

The current study revealed that the prevalence of anemia was $142(28.4 \%)$ in children under ( 5 years) old, this is less than that registered in developing countries, in which $(47.4 \%)$ it is less than that in Abdi Gulled R Shebelle zone, Somali region, eastern Ethiopia et al, when the prevalence of anemia among preschool child is very high (72\%), which indicate, anemia as a major severe public health problem in this community [1]. But it is more than that found in a study done in Kuwait when the prevalence were $(23.0 \%)$ in Kuwaiti preschool children [4] . This may be due to the deference in socioeconomic level and wealth index. Also it is more than that found in Belgium (8.7\%), Austria (10.5\%).
However it is still obviously lesser than prevalence reported in Brazilian studies in which more than one third $(37.4 \%)$ of the children under (60 months) of age from the Minas Gerais state are anemic, in India (74.3\%), Bangladesh (47\%) and in Pakistan $(50.9 \%)$ (15). This may be due to difference between us and other developing and developed country regarding antenatal care and socio-economic status.

The current study showed that 104 (73.5\%) of the children were with iron deficiency anemia, $30(21.0 \%)$ with other cause of anemia and only $6(4.4 \%)$ with thalassemia trait and $2(1.1 \%)$ were B thalassemia. which is in agreement with that found by Mousa AO, et al, 2014, in Basrah city when the prevalence of IDA were (63.2\%) [19]. Akbari 
$M$ et al in his meta-analysis found that the prevalence of IDA was reported in [11] studies fluctuated from $(0.2 \%$ to $57.3 \%)$. By merging the results of these studies, the prevalence of IDA among the children under (6 years) in Iran with the CI of $(95 \%)$ was estimated to be $(20.9 \%)$ [5].

Several studies that is done on a preschool children reported differences in sex-related anemia prevalence, in which the male were more anemic than female, this was similar with our finding were male more anemic than female with significant differences $[12,17$, 14] Because of males more admitted to the hospital than females. Rural area with high prevalence of anemia than urban area with significant difference, which is same that found by [1] when more than two third of the anemic children from rural area. Which is may be attributed to many causes (maternal education, the mother in rural area have many duty in addition to baby care, family number in rural area were more than that in urban) . (Agostoni $\mathrm{C}$ et al) showed that the prevalence of anemia among children exclusively breastfed was of (38.1\%), exclusive breast-feeding more than (6 months) increases the possibility of anemia because $(90.0 \%)$ of the iron requirement comes from complementary foods. In addition, in a recent study done in Pakistan on exclusive breast feeding infants and IDA found that $(26.1 \%)$ of the exclusive breastfed children were iron deficient (18). This is in agreement with that found in our study when the prevalence of anemia in breastfeeding child was $(27.4 \%)$. This may be due no or improper weaning and child need more iron than that taken from breastfeeding in addition to that prolonged exclusive breast feeding is one of the contributing factors for IDA.

Among tea consumption, it has been registered that tea contributes to anemia because tea contains polyphenol which prevent iron absorption. In intestines Polyphenol binds to iron and produce nontransportable complex therefore cannot enter the blood stream instead will be excreted in feces [16]. Highly significant difference were found between patient with worm infestation and anemia than those without which is in accord with that revealed by [7]. This is because intestinal worm infestation results in blood loss in intestine, loss of appetite leading to anemia.

Low educational level and joblessness might lead to poor level of socio-economic status. This is likely to reproduce nutritional deficiencies, infections, and recurrence of infections, which more likely raises the prevalence of anemia. Moreover, education has a relationship with a capacity to hold the awareness needed for adequate healthcare and nutrition for children, therefore low level of education can increase the risk of anemia [23]. Kahigwa et al, 2002 study shown that children with anemia had caretakers who did not finish primary level of education[9].

This is similar to that found in the current study when there is a significant association between the parent's low level of education, non -employed mother (housewife) and the anemic children. Furthermore, Keikhaei B et al, 2007 mentioned that illiterate young 
mother had poor family were more prone to have children with anemia [11]. One of the main predictors of anemia in preschool children were the family wealth index[8], Low wealth index in our study have significant association with anemia which is in agreement with that found in $[23,8,21]$.

\section{References}

[1]Abdi Guled R, Mamat NM, Balachew T, Bakar MA, Azdie W, Assefa N. Predictors and prevalence of anemia, among children aged 6 to 59 months in shebelle zone, somali region, eastern Ethiopia: A cross sectional study. International Journal of Development Research. 2017;7(1):11189-96.

[2]Agostoni C, Decsi T, Fewtrell M, Goulet O, Kolacek S, Koletzko B, et al. Complementary feeding: A commentary by the ESPGHAN Committee on Nutrition. J Pediatr Gastroenterol Nutr. 2008; 46(1):99110.

[3]Akbari M, Moosazadeh M, Tabrizi R, Khatibi SR, Khodadost M, Heydari ST, et al. Estimation of iron deficiency anemia in Iranian children and adolescents: a systematic review and meta-analysis. Hematology. 2017 Apr 21;22(4):231-9.

[4]Al-Qaoud NM, Al-Shami E, Prakash P. Anemia and associated factors among Kuwaiti preschool children and their mothers. Alexandria Journal of Medicine. 2015 Jun 1;51(2):161-6.

[5]Andersson O, Domellöf M, Andersson D, Hellström- Westas L. Effect of delayed vs early umbilical cord clamping on iron status and neurodevelopment at age 12 months: a randomized clinical trial. JAMA Pediatr. 2014;168(6):547-554.

[6]Benoist BD, McLean E, Egll I, Cogswell M. Worldwide prevalence of anaemia 19932005: WHO global database on anaemia. Worldwide prevalence of anaemia 19932005: WHO global database on anaemia. 2008.

[7] Habib MA, Black K, Soofi SB, Hussain I, Bhatti Z, Bhutta ZA, Raynes-Greenow C. Prevalence and predictors of iron deficiency anemia in children under five years of age in Pakistan, a secondary analysis of national nutrition survey data 2011-2012. PloS one. 2016 May 12;11(5):e0155051.

[8]Habte D, Asrat K, Magafu MG, Ali IM, Benti T, Abtew W, Tegegne G, Shiferaw S. Maternal risk factors for childhood anaemia in Ethiopia. African journal of reproductive health. 2013 Sep 1;17(3):110-8.

[9]Kahigwa E, Schellenberg D, Sanz S, Aponte JJ, Wigayi J, Mshinda H, Alonso P, Menendez C: Risk factors for presentation to hospital with severe anaemia in Tanzanian children: a case-control study. Trop Med Int Health 2002, 7:823-830.

[10]Kassebaum NJ, Jasrasaria R, Naghavi M, et al; A systematic analysis of global anemia burden from 1990 to 2010. Blood. 2014 Jan 30;123(5):615-24.

[11]Keikhaei B, Zandian K, Ghasemi A, Tabibi R. Iron-deficiency anemia among children in southwest Iran. Food and nutrition bulletin. 2007 Dec;28(4):406-11.

[12]Kisiangani I, Mbakaya C, Makokha A. Prevalence of Anaemia and Associated Factors Among Preschool Children (6-59 
Months) in Western Province, Kenya. Public Health and Preventive Medicine. 2015;1(1):28-32.

[13]Konstantyner T, Taddei JA, Palma D. Fatores de risco de anemia em lactentes matriculados em creches públicas ou filantrópicas de São Paulo. Revista de Nutricao. 2007 Aug 1; 349-59.

[14]Leite MS, Cardoso AM, Coimbra CE, Welch JR, Gugelmin SA, Lira PC, Horta BL, Santos RV, Escobar AL. Prevalence of anemia and associated factors among indigenous children in Brazil: results from the First National Survey of Indigenous People's Health and Nutrition. Nutrition journal. 2013 Dec;12 (1):69.

[15]Lisbôa MB, Oliveira EO, Lamounier JA, Silva CA, Freitas RN. Prevalence of irondeficiency anemia in children aged less than 60 months: A population-based study from the state of Minas Gerais, Brazil. Revista de Nutrição. 2015 Apr;28(2):121-31.

[16]Ma Q, Kim EY, Lindsay EA, Han O: Bioactive dietary polyphenols inhibit heme iron absorption in a dose-dependent manner in human intestinal Caco-2 cells. J Food Sci 2011, 76:H143-150.

[17]Mamabolo RL, Alberts M. Prevalence of anaemia and its associated factors in African children at one and three years residing in the Capricorn District of Limpopo Province, South Africa. curationis. 2014 Jan;37(1):1-9. [18]Marques RFSV, Taddei JAAC, Lopez FA, Braga JAP. Breastfeeding exclusively and iron deficiency anemia during the first 6 months of age. Rev Assoc Med Bras. 2014; 60(1):18-22.
[19]Mousa AO. Types of anemias with low MCV using Mentzer Index and RBC count among patients seen in Basrah Al-Sadir Teaching Hospital. Med J Babylon. 2014;11:292-6. [20]Ncogo P, Romay-Barja M, Benito A, Aparicio P, Nseng G, Berzosa $P$, et al. Prevalence of anemia and associated factors in children living in urban and rural settings from Bata District, Equatorial Guinea, 2013. PloS one. 2017 May 3;12(5):e0176613.

[21]Pasricha SR, Black J, Muthayya S, Shet A, Bhat V, Nagaraj S, Prashanth NS, Sudarshan H, Biggs BA, Shet AS. Determinants of anemia among young children in rural India. Pediatrics. 2010 Jun 8:peds-2009.

[22]World Health Organization. Iron deficiency anaemia: assessment, prevention and control: a guide for programme managers.2001.

[23]World Health Organization. Worldwide prevalence of anaemia 1993-2005. 2008. http://whqlibdoc.who.int/ publications/2008/978 9241596657 eng.pdf. Accessed October 27, 2017. 